\title{
Feldstein-Horioka puzzle and international capital mobility in high income countries: a pool mean group approach
}

\begin{abstract}
This paper reexamines the status of international capital mobility under the Feldstein-Horioka (1980) hypothesis by comparing the results from the OECD and non-OECD high income categories. Data on savings and investment ratios of 21 OECD and 17 non-OECD countries were analyzed using the dynamic heterogeneous panel estimators of Pooled Mean Group (PMG), Mean Group (MG) and Dynamic Fixed Effects (DFE). Based on the series of Hausman post-estimation test, result from the PMG is upheld. The saving-retention coefficient, showing the level of international capital mobility, reads $0.89,0.93$ and 0.16 for the high-income group, OECD category and non-OECD category respectively. This suggests lower capital mobility in high-income as a whole and OECD countries, and higher capital mobility in the non-OECD countries. The contradictory findings confirmed that the FeldsteinHorioka saving-retention coefficient is unlikely, a viable option of measuring cross-border capital mobility. Further researches therefore need to re-observe the qualification of savingretention coefficient in explaining international capital mobility.
\end{abstract}

Keyword: International capital mobility; Feldstein-Horioka puzzle; Financial integration; Panel data; Pooled mean group; High-income countries 